\section{Falfirkák 2007 Pécs}

— z a cikk nem kiván komoly elméleti fejtegetésekbe bocsátkozni a street att elméle megitélését, minôsítését illetôen. Nem megyünk bele abba a elméleti zsákutcába, hogy mưvészet-e az utcamũvészet, és van-e létjogosultsága a városok közterein. Nehezen ugyan, de megálljuk az értékelést, a graffitik és stenci lek jelentỏségének kihangsúlyozását, nem általánosítunk, nem bélyegzünk me senkit, nem védünk és nem támadunk. Vizsgálódunk, dokumentálunk, tesszük azt ami a szociológus dolga, amikor találkozik egy olyan jelenséggel, amit nem lehet nem észrevenni, ami ránk kiált a házfalakról.

\section{A kutatás ${ }^{1}$}

A város utcáin és köztexein található képek, rajzok, szövegek - összefoglaló néven falfirkák - kutatásában 11 szociológus hallgató vett részt egy kutatószeminárium keretében. A kutatás lépcsôzetesen épült fel, a kvantitatív kutatást megelôzte egy interjúkta alapozott elemzés, amely egy másik vizsgálat részét képezte, ugyanakkor a falfirka-kutatás elméleti elôkészitését megalapozta. Az elökészítô vizsgálat 2006 tavaszán zajlott le, amikor számos interjút készítettünk a pécsi underground szféra képviselöivel, street artosokkal, zenészekkel, Dj-kel, illetve kortárs, fratal mưvészeti egyesületek vezetỗivel, akik étintettek a falfitkálásban vagy érintkeznek, kapcsolatban állnak velük. Az interjúk elemzése során nyert információk, összefüggések nagymértékben orientálták a dokumentáló munka felépitését, hangsúlyait, illetve az eredmények értékelését is elősegitették.

\section{Elméleti alapvetés}

1. A vizsgálat tárgyának kijelölése: A kutatás tárgyát azok a közterület különbözó objektumain, a magánházak falain, illetve a hozzá tartozó felületeken megjelenỏ írott vagy/és rajzolt, festett, nyomtatott - az esetek nagy részében illegális - vizuális jelek alkotják, amelyeket graffitinek, stencilnek és matricának nevezünk.

2. A basznált fogalmak meghatározása

2.1 Illegális vizuális jel: A közterület különbözõ objektumain, közlekedési eszközökön, a magánházak falain, illetve a hozzá tartozó felületeken megjelenó vizuális jelek, melyek a tulajdonosok akarata ellenére vagy azzal nem egyeztetett módon vagy formában kerültek oda. Ide tartozik minden olyan illegá- lisan kiragasztott, kifüggesztett, vetített reklámanyag, bármilyen célból kihelyezett plakát, matrica, bármilyen falra vagy egyéb objektumra írt, rajzolt festett jel, amelynek megjelenítését a tulajdonos nem engedélyezte.

2.2 Jogszabály: 2004-ben módosították a Büntetô Törvénykönyvet, a rongálás szakaszát kiegészitették a „graffitizés” cselekményével. A Büntetỏ Törvénykönyvrôl szóló 1978. évi IV. törvény a következőképpen egészül ki: "Graffitizés 324/A.S (1) Aki idegen vagyontárgyon festékkel, tintával vagy bármilyen más anyaggal nyomot hagy és ezzel kárt okoz, grafitizést követ $\mathrm{el}^{\text {"22 }}$ (Btk. 2004. évi törvénymódosítása, 324/A.D). A graffitizés mint jogsértés lehet szabálysértés vagy bũncselekmény. Amennyiben az elkövetők által rajzolással okozott kár értéke nem éri el a $10.000 \mathrm{Ft}$-ot, úgy velük szemben szabálysértési eljárás indul, mely $100.000 \mathrm{Ft}$-ig terjedô pénzbirsággal sújtható. Ezen eljárás lefolytatására az illetékes önkormányzat jogosult. Amennyiben a kár értéke meghaladja a 10.000 Ft-ot, úgy bũncselekmény miatt indul büntetőeljárás.

2.3Vizuális környezetszennyezés: A közterület különböző objektumain, közlekedési eszközökön, a magánházak falain, illetve a hozzá tartozó felületeken, valamint az egyéb építményeken közszemlére kitett vizuális jelek, melyek függetlenül attól, hogy a tulajdonosok akaratával egyezően vagy annak ellenére, vele egyeztetett vagy nem egyeztetett módon vagy formában kerültek oda - a közízlést sértik, rombolják, s az általánosan elfogadott erkölcsi, esztétikai, jogi normáknak nem felelnek meg.

2.3.1 Legális: Ennek jó példája és a városlakó bosszúságának gyakori okozója: a reklám. A reklám legáltalánosabb értelemben a kommunikáció egy formája, amely egy bizonyos áru vagy szolgáltatás megvételére, igénybevételére ösztönöz ${ }^{3}$. A köztereken vagy a közlekedési eszközök oldalán elhelyezett reklámok legalább ugyanolyan eséllyel indulnak a vizuális környezetszennyezés-minôsitésért, mint az utcamûvészet, viszont legálisak. Gyakran előfordul, hogy az illegálisan mûködő furkászokból jól fizetett reklámgrafikusok lesznek, sôt olyan is van, aki mindkettőt(!) csinálja. A legális vizuális kömyezetszennyezésbe tartoznak még a városi funkcionalitás és díszítőkedv egyéb, kivédhetetlen csúfságai is (pl. csúnya térelemek, virágtartók, szemétgyũjtő edények, giccses ablakok és kerítésdíszek, stb.).

2.3.2 Illegális: Street art A street art egyesek szerint rongálás, vizuális környezetszennyezés, mások szerint utcaművészet. A street art nyitott fogalom, egyes szerzôk, mưvészek minden olyan mûvészeti céllal készült munkát, elóadást, akciót ide sorolnak, ami az utcán, a köztereken történik vagy megjelenik. Talán ez a legbefogadóbb és legnyitottabb felfogás. Mások a köztereken megjelenổ vizuális képeket, rajzokat, szövegeket sorolják ide, elkülönítve ettôl az előadásokat, performance-okat, akciókat, még ha azok köztéren is történnek. Ez talán a legelterjedtebb felfogás. A street art leoszükebb értelmezésébe csak a stencil és a matrica fér bele, a graffiti már nem. A graffitit a közönséges és gyaktan csúnya tagek teszik mưvészeti szempontból 
szalonképtelenné. A matrica határeset, mert bár általában a stencilesek készitik a matricákat is, de a matrica erôs, direkt tátsadalmi, politikai, kömyezetvédố, globalicációellenes üzenetei miatt inkább a public artba sorolódik. A stencilek között is találunk - fổként a politikkai kampányok időszakában olyan ellenszlogeneket, mint pl. „Ne szavazz, szerveződjp” Tehát a public artnak vannak olyan formái is, amelyek nem egykönnyen választhatók el a street arttól, annak részeként is felfoghatók, és természetesen mint falfirkák illegálisak. Egyébként a public art legális, legalábbis a nyugati országokbat gyakran állami támogatással valósulnak meg olyan köztéri, közösségi akciók vagy kihelyezett mưvek, amelyek szociális, illetve társadalmi célokat szolgálnak. A public art társadalmilag elkötelezett mủvészet (New Genre Public Art), amelyet mostanában a "mûvészet a köz érdekében" fordítással lehet magyar nyelvre áttenni (Hock 2005: 99). Tehát a public art nem tartozik a vizuális kömyezetszennyezés körébe, mert nem illegális és nem izléstelen, szemben a reklámok nagy részével. Kutatásunknak nem volt tárgya a public art, csak a fogalmi tisztánlátás miatt tértünk ki erre. (Egyébként a vizsgált idôszakban a közösségfejlesztők egy Pécs-Meszesen zajló szociálisművészeti projekt keretében életre hívtak egy ilyen alkotást.)

2.4/A Graffiti: Eredeti jelentése: felitat. Ha a jogszabály fogalmát fogadjuk el, elég tágra nyitjuk a graffitizés körét, mert az összes rongáló graffitizik, aki lehasít egy darabot egy fapadból, vagy végig karcol egy autót, azaz nyomot hagy más tulajdonán, s ezzel kárt okoz. „A graffiti/falfestészet az új és szabad önkifejezés, az önmegvalósitás, a kapcsolatteremtés, a valahová tartozás, egyfajta menekülés eszköze a mûvelöik számára, ugyanakkor az esztétikai dimenziója gazdagitja a személyiségüket. A graffiti egyszerre élet- és magatartásforma, életstilus, szórakozás, ill. díszítốművészet” (Hajdú 2001)4. A gtaffiti készitésekor általában szabad kézzel, elổre megtervezett vázlat alapján történik a rajzolás, fújás, kontúrozás. A kivitelezés gyakran több (legalább három ember) részvételét igényli. A graffiti inkább közösségi, mint individuális múfaj, minden rajz, firka egyedi, nem sokszorosítással előállított. A graffiti lehet pusztán szignó vagy karakteres. A graffiti a street art körébe tartozik, még akkor is, ha sokan a tagek miatt kizárják ebből a kategóriából. Sugár János (Kriminalizált müvészę) a street art körébe sorolja a graffitit is, ami pedig a tagek általános elutasítását illeti, a következőképpen nyilatkozott errổl a kérdéstôl: "Az összes graffiti-mủfaj mélyén a tag van, mert a tag az, hogy 'én vagyok, az én nevem, becenevem, akármim' - lehet színesben, nagyban, az ugyanaz. Szerintünk hatalmas félreértés ezekben minőségi különbségeket keresni, mert ez közösségi mûvészet, amiben a közösségi szempont dönt. Aki tagel vagy graffitizik az nem azétt fest az utcafalakra, mert nincs otthon papír vagy nincs pénze vászonra, hanem azért, mert ez egy közösségi mũfaj. A többségi társadalomnak az a képviselôje, aki megpróbálja a jó és rossz graffitit vagy a 'még nem művészet, már nem mûvészet' kategóriáját belevinni, az legjobb esetben is buta, és becsapja önmagát" (Kriminalizált müvészet).

2.5/B Stencil: Stencilnek nevezzük azt a képet, szöveget vagy képet és szöveget, amelyet egy elổre elkészitett sablon segitségével, festékkel történō körbe fújásával vagy festésével hoz létre a készítōje. Maga a kivágott sablon teszi lehetôvé a sokszorosítást, az elöállitott darabok mennyiségének csak a sablon stabilitása, minősége szab határt. A stencil kifejezés a franciában a nyomdaiparból, az angolban a gyártástechnológiából származik. Mindkét kifejezés közös vonása, hogy sablont vagy mintadarabot jelöl (Day 1987). A stencilek közül a köztéti objektumokra kikerülổ képeket vagy feliratokat a street arthoz vagy utcamúvészethez soroljuk. Stencilképek papír alapra is készülhetnek, ennek egyik formája az öntapadós matrica vagy a plakát. A plakát mưfajával Pécsett, az adott időszzakban lefolytatott kutatás során nem találkoztunk (leszámítva a 2006-os év kampányidốszakát). A plakát terjedésének manapság a szegedi street artosok körében lehetünk tanúi ${ }^{5}$.

2.5/C Matrica: Kis méretủ öntapadós papír, amire bármit tá lehet nyomtatn vagy szabadkézzel ími, majd kiragasztani. A matricára stenciltechnikával is felkerülhet a kép, a rajz vagy a szöveg. A legkisebb felületet ez foglalja el, és soha nem ragasztiák falakra, igy legkevésbé szembeötlő, mégis szinte ez hordozza a legtöbb és legteljesebb üzenetet (a politikai kampányok kedvelt eszköze). Érdekes, hogy ezzel szemben matricával találkoztunk a legkevésbé a városban. Gyakoriak viszont a hirdetô matricák, amelyek nem tartoznak kutatásunk tárgyai közé.

3. A fogalmak összefüggésének magyarázata: A graffiti, a stencil és a matrica nem tartozik egyértelmúen az illegális vizuális jelek közé, mivel megtalálhatók a kijelölt legális falakon is, továbbá a matrica a politikai kampányok bevett eszközének számít, s mint ilyen, a szokásjog szerint a „,megtûrtt" kategóriába tartozik, annak ellenére, hogy kimeríi az illegális vizuális jel fentebb ismertetett fogalmát. A vizuális környezetszennyező̉k köre nem szükíthetổ le a falfirkálókra, ebben a körben komoly eséllyel indulnak a köztereken kihelyezett reklámok, a politikai plakátok, szórólapok, ragasztmányok, továbbá a nem túl tehetséges hatósági emberek, hivatalok, vezetők által engedélyezett csútul tén áánytalan, izléstelen köztéri objektumok, produkciók, vagy a magánházakon vagy az azokhoz tartozó területen közszemlére kitett kevéssé esztétikus diszek, szimbólumok, vizuálisan érzékelhetổ jelek, hogy csak a legjelentősebbeket emlitsem. A vizuális kömyezetszennyezés kategóriájába tartoznak a slumosodó kömnékek vagy a gettók lepusztuló épületei, az emberi finak a slumosodo könyer minden fajta közszemlére kitett látványa, de a kevésbé mellbe vágó, de annál gyakoribb omladozó, málladozó falak képe. A vestiti, stencil, matrica ezekhez képest akár üdítỏ is lehet, különösen ott, ahol a firkász éppen az említett vizuális anomáliákra kívánja felhívni a figyelmet a maga sajátos módján. Nem ritka, hogy egy-egy szépen kidolgozott graffiti vagy stencil esztétikai értéket hordoz, tehát ezeknek a vizuális múfaj- 
oknak a vizuális kömyezetszennyezés körébe történő besorolhatósága nem egyértelmû. A viszonyítás és a kömyezet milyensége sem mellékes, amikor a falfirkálók tevékenységére a közízlés és a jog nevében kíván lesújtani a társadalom.

4. A viæsgálat célja: Egy adott időszakban pillanatfelvételt kívántunk késziteni egy magyar megyeszékhely (Pécs) épületein és köztéri objektumain található összes falfirka, rajz és festmény milyenségéről, összetételérôl és a közvetített üzenetekről. Ezen kívül szerettük volna a város mentális térképét megrajzolni a sűrüsödési pontok mentén. A szövegek és képek készitői a társadalom fratal tagjai, akik tevékenységükkel üzenni kívánnak a többségi társadalomnak, s ezt az üzenetet nem ártana megfejteni, már csak a békés együttélés miatt is. A megértés elsô lépése a szociológus számára a tények számbavétele, feltérképezése és értékelése, az üzenetek megfejtése - a műfaj jellegéböl fakadóan ez másként nem lehetséges.

5. Elôfeltevések: A falfirkákon belül a graffiti és a stencil elég élesesen elkülönül nemcsak az alkalmazott technika miatt, hanem területi elôfordulásuk szerint is. A graffitik, stencilek és matricák elhelyezkedése a városban nem egyenletes, preferált pontok a belváros és kömyéke, illetve a lakótelepek.

\section{Az adatfelvétel gyakorlati menetének és módszereinek leírása}

Az elméleti alapvetés után 2007. március 15. és május 15. között, tehát két hónap alatt hajtottuk végre a keresztmetszeti vizsgálatot, melynek során Pécs Megyei Jogú Város közterein és utcáin található összes graffiti, stencil és matrica dokumentálása megtörtént.

1. A város területét 8 egységre osztva végezték el a munkát a Szociológiz Tanszék hallgatói. A területeket úgy alakítottuk ki, hogy a köztudatban is meglévő egységet alkossanak. Igy jött létre 8 nem egyenlố területet, utcák szerint pontosan lehatárolva.

A területi egységek (körzetek) a következök voltak:

- Történelmi belváros: városfal által határolt terület.

- Tágabb belváros/A

- Tágabb belváros/B

- Tágabb belváros: Mecsek-hegyoldal

- Tágabb belváros: Gyárváros

- Uránváros: Tüzér utca- Kürt utca

○ Kertváros

- Meszes

2. A város közterein és utcáin található összes graffiti, stencil és matrica dokumentálása során a különbözỏ objektumokon talált falfirka pontos helye, elhelyezkedése, nagysága színe, állapota stb. adatlapon és digitális fénykép formában rögzítésre került.

Az adatlapon az alábbi adatok szerepeltek:

- Utcanév, házszám, azonosítószám

- A felület pontos megnevezése, amin a rajz vagy szöveg található: fal, ablak, kapu, kerítés, palánk, áramszekrény, egyéb

- $\quad$ A körzet pontos megjelölése. Erre azért volt szükség, mert egy területen többen is dolgoztak

- A falfirka becsült mérete (a graffitiket négyzetméterben, a stencileket és a matricákat négyzetcentiméterben meghatározva)

- A talajszinttől számított magasság (méterben, illetve cm-ben megadva). Ez nagyon fontos tényező, mert minél magasabban található pl. egy graffiti, annál értékesebb az alkotók körében. A nehezen elérhetô hely értéknövelõ tényezõ

- Szinek pontos megjelölése

- A falfirka aktuális állapotának rögzítése (3 kategória szerint: jỏl látható, elhalványuló vagy rosszul kivehetô)

- A falfirka tartalma: kép vagy kép és szöveg együtt vagy csak szöveg

- A tageket szignóként (szövegként) kezeltük

- $\quad \mathrm{Az}$ adatlap külön rovatában szerepelt a kép vagy szöveg egyszerú leírása, amely lehetỏvé tette az azonosságok kiszürését a feldolgozás során (a fényképen történỏ azonosítás nélkül is)

3. Az adatlapokat és a hozzá tartozó fényképfelvételt elláttuk ugyanazzal a kódszámmal, a későbbi pontos azonosíthatóság miatt.

4. Az adatlapokat ellenőrzés után kódoltuk, a kódokat egy további egyeztetés és ellenôrzés után Excell program segítségével számítógépen rögzítettük.

5. Az adatlapon szereplỏ rovatok csak az elõfordulások gyakoriságának leírását tették lehetỏvé, ami a dokumentációs és kvantitatív összegzéseket célzó kutatásunk voltaképpeni lényege. Az információk összegzése után elkészítettük a város mentális térképét, amely választ ad arra, hogy hol sưrũsödnek a falfirkák, a „Miért?” kérdésére azonban nem válaszolnak.

Az alkalmazott módszerek rövid összefoglalása

- Teljeskörú mintavétel (kivétel: az ugyanazon a felületen többször előforduló azonos szignót csak egyszer dokumentáltuk) 
- Keresztmetszeti vizsgálat

- Területi egységek szerinti felosztás

- Adatlapon és digitális felvételeken történô dokumentálás

- Adatfeldolgozás, adatellenỏrzés

- Adatelemzés: előfordulások, típusonkénti gyakoriság vizsgálata

- Mentális térkép készítése

\section{A dokumentáció feldolgozásának elvei és eredményei}

A feldolgozás szakaszában megpróbáltuk minden esztétikai elôitélettôl mentesen szemlélni és rendszerezni a gyưjtött anyagot. Az egyszerü megoszlások, gyakoriságok elemzése is rengeteg olyan információhoz juttatja a kutatót, amely a későbbi minőségi elemzés során nyeri el igazi értékét. A falfirkákról vagy a falfirkászokról készült írások stilusára, a megközelítés elfogultságára gyakran a bennfentesség, az involváltság vagy éppen az ellenkezôje, a jog alapján álló merev elutasitás jellemző. A szociológus a tények korrekt összegzésével megpróbálja távol tartani magát az elfogultság mindkét változatától. Egyszerũen szólva: leírjuk, amit látunk, annál nem többet és nem kevesebbet - a megítélés nem a kutató dolga. Nem értékítéletet kívánunk megfogalmazni, csupán ábrázolni egy adott helyzetet. A tények leírása nélkül esély sincs arra, hogy a falfirkálás problémájáról érdemi diskurzus kezdődjön a társadalomban.

\section{A felïlet}

A fclület megválasztása egyáltalán nem lényegtelen, hiszen ebben a mũfajban ez eleve szétválasztja a közterek és magánházak, valamint az azokhoz tattozó területeken található objektumokra felkerülố vizuális jelek fajtáit. Nagyon gyakran a készítés technikájával függ össze, hogy milyen felületre helyezhető ki. Matrica nem kerül házfalra, mert nem ragad rá, ezért ezt elsősorban fémre ragasztják, ahonnan egyébként letéphetô, kis erôfeszítéssel levakarható. A matrica kihelyezését ezért nem is tartják rongálásnak, s mint azt fentebb már említettem, politikai kampányok esetén bevett, „szinte legális” eszköz. Ezzel szemben a graffiti zömében falakra kerül, minél nagyobb méretũ, annál helyigényesebb. A graffiti rongál leginkább, az alkalmazott technika által „használt” felület jellege és nagysága miatt. A stencil nemcsak falakra, keritésekre kerül, hanem gyakran fémfelületekre (áramszekrényekre, fémből készült szemétgyüjtőkre stb.).

A graffitiket sima falfelületre szeretik leginkább felfújni a készítők (gyakori felüljárók tartóoszlopa, pillére, valamint kỏkerítések). A stencileket, hasonlóan a graffitihez, sima falfelületre fújják leginkább, hiszen a sablon, amit körbefújnak, csak így illeszkedik pontosan. Stencilt ezen kívül nagy számban fújnak fel még áramszekrényre. A matricát - a fentebb már kifejtettek miatt - szinte csak fém felületre (csatomaereszre, áramszekrényre, villanyoszlopra, olykor közlekedési táblára) ragasztanak. A matrica elônye, hogy séta közben a tenyérbe rejtve egy mozdulattal felragasztható, kicsi a lebukás veszélye, mivel a munka elsősorban otthon történik.

Fontos emlitést tenni arról, hogy a graffitik több mint háromnegyede falfelüleen található, de ebből igen jelentôs hányad a Boccaccio „legál falain” (ez mát múlt idô) és a vasút melletti kőfalon és kerítéseken található. Ezek a graffitik lakatlan

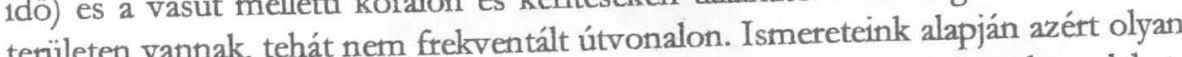
közkedveltek ezek a falak és keritések a graffitisek körében, mert igaz, hogy lakatlan ám mégis, ha jól belegondolunk, a vonatról pompás kilátás nyilik rájuk. Ez a lé íñ sźn távol helyezik ki ezeket a többnyire nagy alakú képeket vagy igényesebben kidolgoméretes betúkből álló tageket. A vonatokra is ezért fújják a jeleket, képeket, zott meket. A vonat tovább viszi más városokba, megmutatva magát így más kéter ki k a vonatokła fújt rajzok-

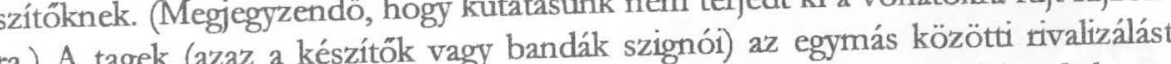
a.) A trokenAtatják, elsôsorban területjei

tált belvárosi közterületeken.

\section{A környéke}

1. ábra: Graffitike aránya a terület minöségébez mérve

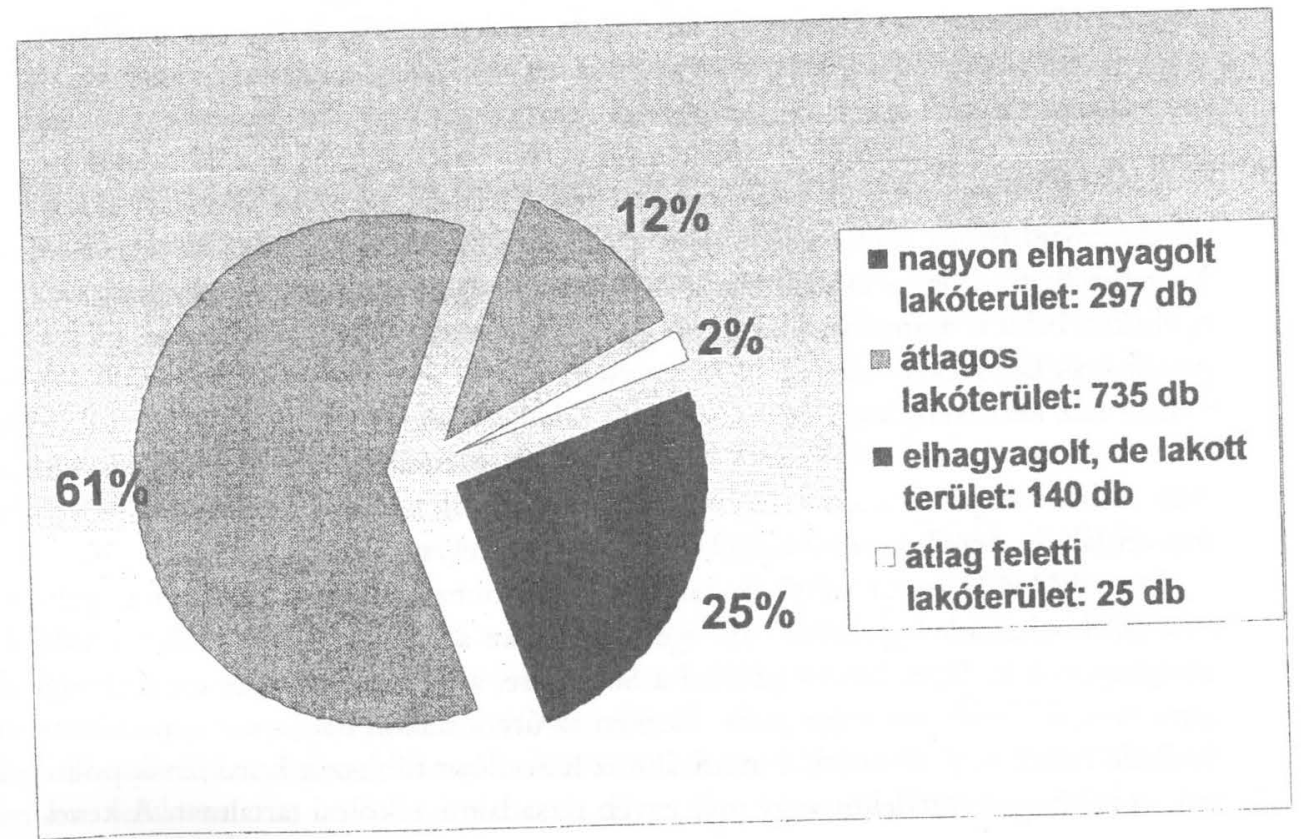




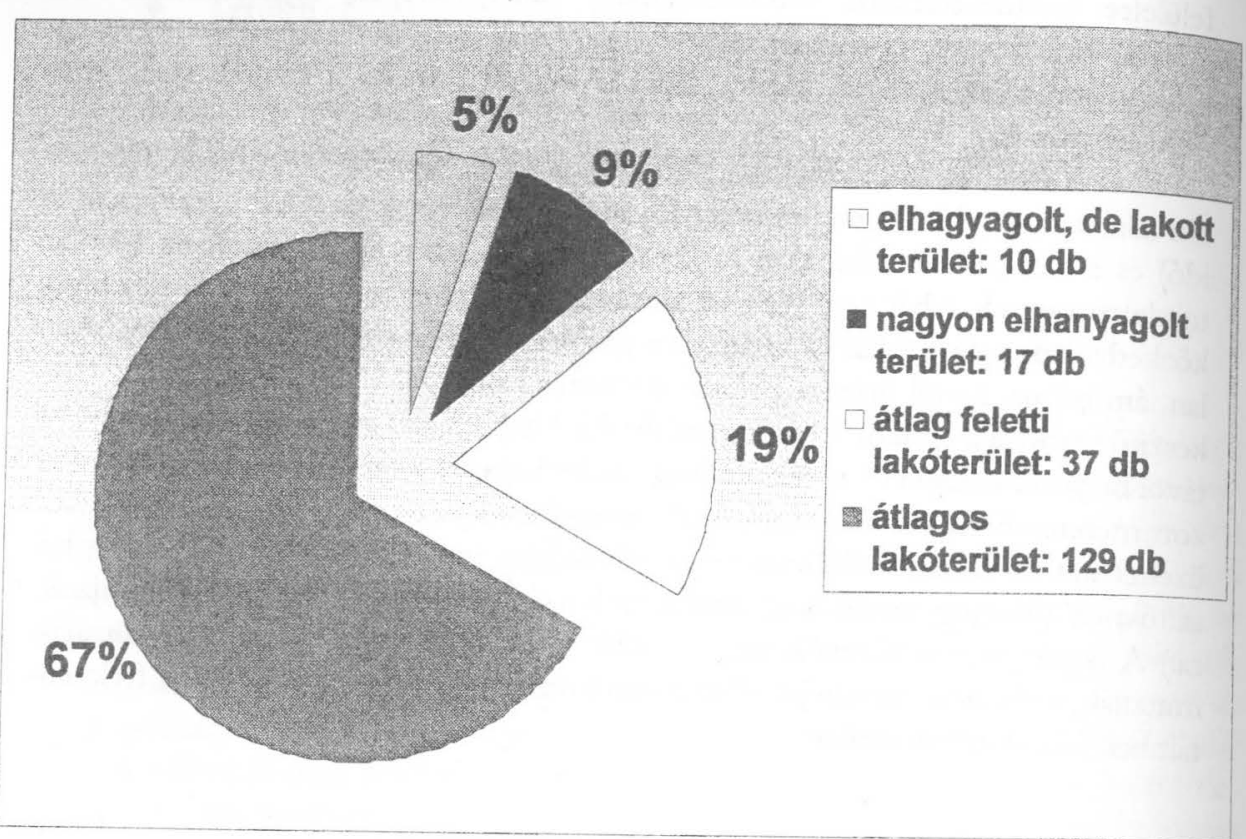

Adatlapjainkon a területek minôségét 4 különbözỏ kategóriába különítettük el. A skála szerinti felosztásban: az 1. kategória a teljesen elhanyagolt, lakatlan területet jelezte; a 2. kategória elhanyagolt, ám lakott területet jelöl; a 3. pont az átlagos lakóterületek, panelházak, kertes házak övezete; a 4. kategória pedig az átlag feletti ún. villanegyed volt. Ezeket a kategóriákat előre pontosan lehatárolt szempontok jellemezték. (A diagrammon e szerint a felosztás szerint olvashatóak az adatok.)

Látható, hogy graffitikkel átlagos területen, lakóterületeken találkozhatunk leginkább, majd ennek szinte ellentétével a nagyon elhanyagolt lakatlan térségekben. Megállapítható, hogy a családi házas övezetben még az átlagos (3. kategória) környékeken belül is arányában kevesebb graffiti és általában falfirka található, mint a panelházak környékén. Ennek az az egyszerũ oka, hogy a firkász nem mászik át a családi ház kerítésén, hogy egy olyan falra firkáljon, amit mondjuk a növényektől senki sem lát. Az ún. átlag feletti körzetek villanegyedeiben (4. kategória) ugyanezen okból elenyészõ mennyiségben találkoztunk velük, annál inkább a belváros frekventált övezeteiben, a keritéssel nem védett részeken.

Stencilekkel és matricákkal, hasonlóan a graffitihez, az átlagos, lakott térségekben találkozhatunk leginkább. Ám igen magas az átlag feletti lakóterületen való megjelenésük is. Ilyen helyek például a Séta térre, a Színház térre, és a Széchenyi térte vezetô kisebb belvárosi utcák. Ezeken az útvonalakon nap, mint nap számos járókelổ halad el. A stencilek a matricákhoz hasonlóan többször hordoznak politikai, akár kömyezetvédelmi vagy más egyéb társadalmi, erkölcsi tartalmat. A készí- tốk feltehetỏen ezért helyezik el ôket a belvárosban, az adó vevổ nélkül mit sem ér. A firkászok célja a figyelemfelkeltés vagy/és akár a polgárpukkasztás.

\section{Méret és magasság}

A graffitik átlagos mérete 4,7 négyzetméter, ami nagyon nagynak tủnik. Ezt azt igen magas számot a legál falon található ótiásinak mondható, olykor 30-40 négyzetméteres graffitik miatt kapjuk. Van olyan festmény, ami eléri a 62 négyzetmétert. A graffitik vizsgálatakor fontos a magasság is, mivel az interjúkból kiderült az is, hogy a graffiti annál értékesebb, minél lehetetlenebb helyen található. Ennek magyarázata az, hogy minél magasabban van, annál nehezebb felfesteni. Ilyeneket a Boccaccio és vasút melletti betonfalakon lehet látni.

A stencilek átlagosan 23 négyzetcentiméteresek. Vannak a városban azonban olyanok, amelyek elérik az 1, akár a 1,5 négyzetmétert is. Ezekbôl nincsen sok a városban, de ezek a legszebbek és leglátványosabbak. A matricák átlagosan 6,3 négyzetcentiméteresek, a matricák közül ezek a leginkább szembetủnőek. Ezek a matricák a laikus számára könnyen összekeverhetôk a hirdetổ matricákkal.

A falfirkák elhelyezésének magassága nem függ össze a kép vagy a szöveg méretével, pedig eredetileg ezt feltételeztük. A graffitik nagy része a vasút és a felüljárók környékén a földtổ vagy pát cm-rel feljebb kezdôdik, méghozzá függetlenül attól, hogy mekkora a területe. Ugyanez a helyzet a legál falon vagy a Boccacció falain elhelyezett graffitik esetében. Ahogy elfogy a hely, úgy helyezik feljebb vagy lejjebb a rajzot. Ezeken a falakon kevés a hely, és el kell férni vagy másét lefesteni, ami torzsalkodást szülhet, mi több, a gondosan kivitelezett alkotás késôbbi sorsát is veszélyezteti. Aki nem tartja tiszteletben másét, az maga sem számíthat kíméletre. Ezek a graffiti alaptörvényei. A vasút körüli területek és a felüljárók szintén nagy felületeket kínálnak, jól láthatók és munkára alkalmas terepek.

A lakott részek házfalain elhelyezett graffitik magasabban helyezkednek el, ahogy kényelmes az alkotónak, vagy ahogy még létráról elérhetô. A magasabban elhelyezett rajzok elônye, hogy megerôltetổ ráfesteni, tehát nagyobb a túlélési esélye a firkának, ami emeli a firkász presztizsét. A lakóházakon vagy középületeken, frekventált helyeken elhelyezett szövegek és rajzok értékét az adja, hogy merészség kell a felviteléhez, tehát adrenalinfokozók, másrészt valóban sokan látják, ha úgy tetszik, sokakat sikerïl bosszantani vagy elgondolkodtatni ezekkel, ugyanakkor ezeket - érthető módon - elég hamat eltakaritják.

A stencilek elhelyezésének magassága hasonló elvek szerint müködik, legalábbis a fentebb ismertetett területeken. Az áramszekrényekre fújt stencileket igyekeznek arányosan elhelyezni, férnfelületre többnyire csak egy-egy kép ketül. A matricák elhelyezkedési magassága leggyakrabban szemmagasságban van, de az 50-80 cm-es magasság is gyakori, mert ilyenkor az aktor vagy a politikai aktivista elhaladtában a tenyerében meghúzódó matricát nyomja fel az ereszcsatomára vagy bátmilyen fém felületre 
3. ábra: Az alkotások szinbeli eltérései (db)

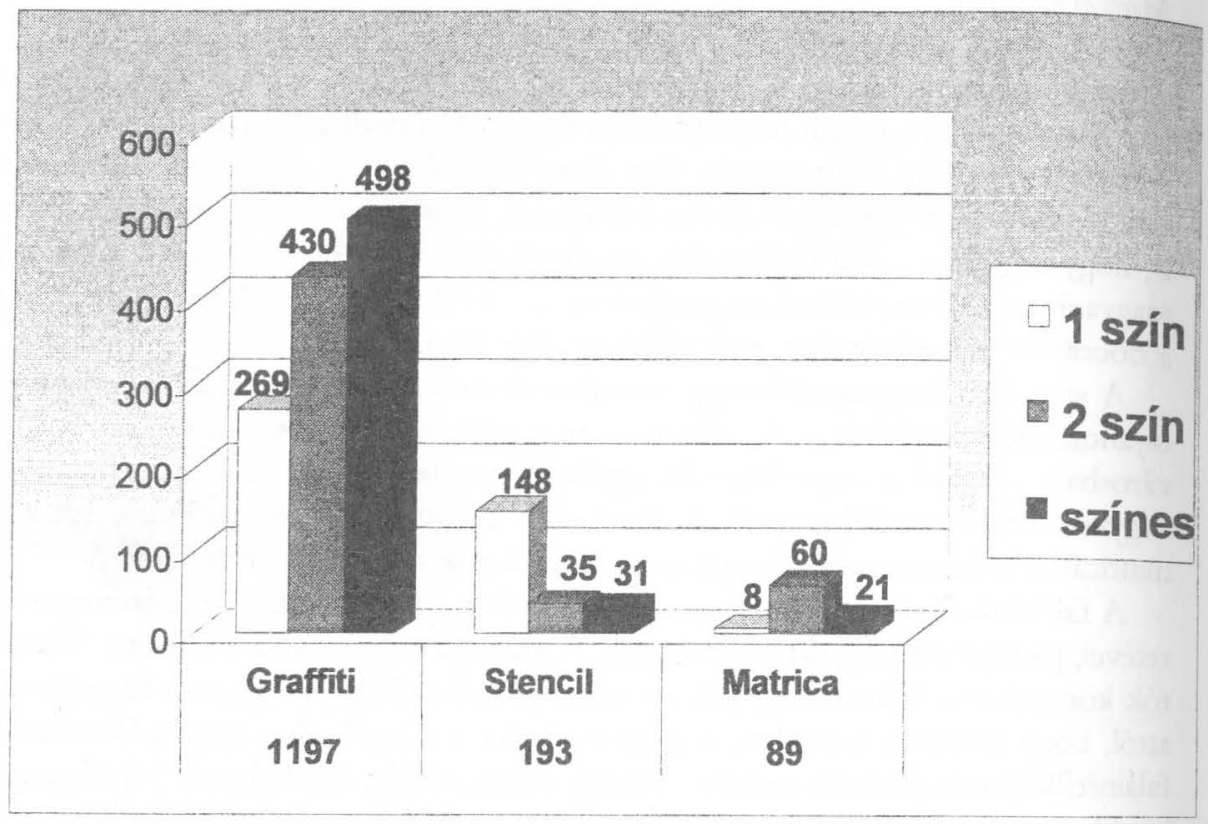

A diagrammból látható, hogy a graffitik többsége színes, csak kevesebb mint egynegyedük (22\%-a) egyszinû. Az egy szín gyakorlatilag feketét jelent. Az egyszínû graffitik mind tagek, vagyis szignók, amelyeket a készitők pillanatok alatt felfújnak vagy filccel felímak a falakra, és amelyek a leginkább bosszantóak. Ezek a szignók többnyire semmiféle esztétikai értékkel nem bímak, s a puszta rongáláson kívül azt mutatják, hogy az illetô itt járt, s erről értesíteni kíván mindenkit, különösen azt a bandát, ahol valószínủleg még a „tápláléklánc” végén van. Ezek között a falfirkák között elvétve, de találunk néha egy-egy angol nyelvũ vagy magyar mondatot, ami szól valamiről és üzenni kíván.

A tagek bonyolultabb, némileg esztétikusabb, de ugyanannyira értelmetlen változatát alkotják a két szín kombinálásával létrejött tagek, amelyek fekete kontúros kivitelezésével általában a banda nevét tisztelik meg a firkászok vagy a saját, feltehetôleg éppen emelkedő hímevüket. Ezeknek a firkáknak, ha van egyáltalán üzenete, az a graffitis társadalomra irányul, a nyilvánosságra ebbôl csak annyi tattozik, hogy itt vagyok, itt vagyunk, ez a mi területünk.

A több szín (legalább 3) kombinációjával létrejött graffitik esztétikailag a legigényesebbek, $\mathrm{s}$ ha az üzenet nem több, mint banda-jel, akkor is a kivitelezés minősége emeli az értékét. A legszebb képes graffitik a legál falakon fordulnak elố,
$(498 \mathrm{db})$ szines, ami azt jelenti, hogy az utcamủveszetnek ez a legkaromoltabb válfaja is törekszik egyfajta igényességre. A vizsgálatból kitünik, hogy a színek sokfélesége összefügg az igényességgel, így a falfirkák esztétikai értékével is.

A stencilek többsége egyszínû, kevés áll háromnál több színböl. Ebben a mû́fajban a kivitelezés és a tartalom igényessége összhangban áll. Ugyanakkor éppen a stencil az, ahol nagyon szép és pontosan kivitelezett alkotásokat láthatunk egy színben is, s még véletlenül sem jelenik meg a graffitire jellemző mennyiségi mérce. A stencilek több mint kétharmada egy színnel készül. Véleményünk szerint csupán azért, mert itt a munka értékét elsősorban a pontos kivágás és a kivitelezés adja és nem a színek harmóniája. A stencilek gyakran ábrázolnak személyeket, híres arcokat (karaktereket), amelyek pontos és érzékletes megjelenítése ezzel a technikával korántsem egyszení. Ebben az esetben a hangsúly magán a témán van, azon hogy készítője mennyire volt kreatív és ötletes, valamint, hogy mennyire volt pontos az alkotás kidolgozásakor.

A matricák közül a színesek a legszebbek, legtöbbet mondóak, azonban ezekből meglehetősen kevés van, csupán a matricák $24 \%$-a tartozik ide. Ebben a mûfajban a két színben történő kifejezés dominál, a matricák 67\%-a kétszínủ. $\mathrm{Az}$ egyszinü, gyakran hirdetéste emlékeztetỏ matricákból ( $9 \%$ ) szerencsére kevés van. Ezek a szöveges vagy a nagyon hangsúlyozott alakos megjelenésen keresztül a direkt mondanivalóra, üzenetre koncentrálnak, ennél fogva gyakran nélkülöznek minden mûvészi áttételt.

A dokumentáló munka során megszámlált és rögzített alkotásoknak (1479 db) kb. egyharmada $(550 \mathrm{db}$, azaz $37 \%$ ) színes, tehát 3 vagy annál több színböl áll ugyanígy $525 \mathrm{db}$-ot ( $35 \%$ ) két szín alkot, a többi ( $594 \mathrm{db}-40 \%$ ) esetében pedig egy szint alkalmaztak. Ezek sokkal igényesebbek és gondosabban kivitelezettek, mint az imént említett szignók. Ezekbe az alkotásokba maguk a készítők is sok pénzt ölnek (egy flakon szórófesték 800-1000 Ft között mozog), valamint sokszor otthon elöre megtervezett munka előzi meg a festést.

Ezzel szemben, mint az előbb láthattuk, a graffitik esetében a színek is nagy hangsúlyt kapnak. Graffitisekkel készített interjúkból kiderült, hogy annál értékesebb egy graffiti, minél nagyobb és minél színesebb. Ez a mưvész ügyességét, tehetségét és nem utolsó sorban elhivatottságát tükrözi. A festék drága, a kihelyezés hosszadalmas és veszélyes, aki színeset, nagyot és kidolgozott mưvet csinál, az komolyan veszi. Egynémely színekben és formákban gazdag graffiti elkészítése (pl a piece) profi munkát kíván, hosszú elkészítési ideje miatt általában legál falra kerül. 


\section{4. ábra: Az alkotások alakzati kïitönbségei (db)}

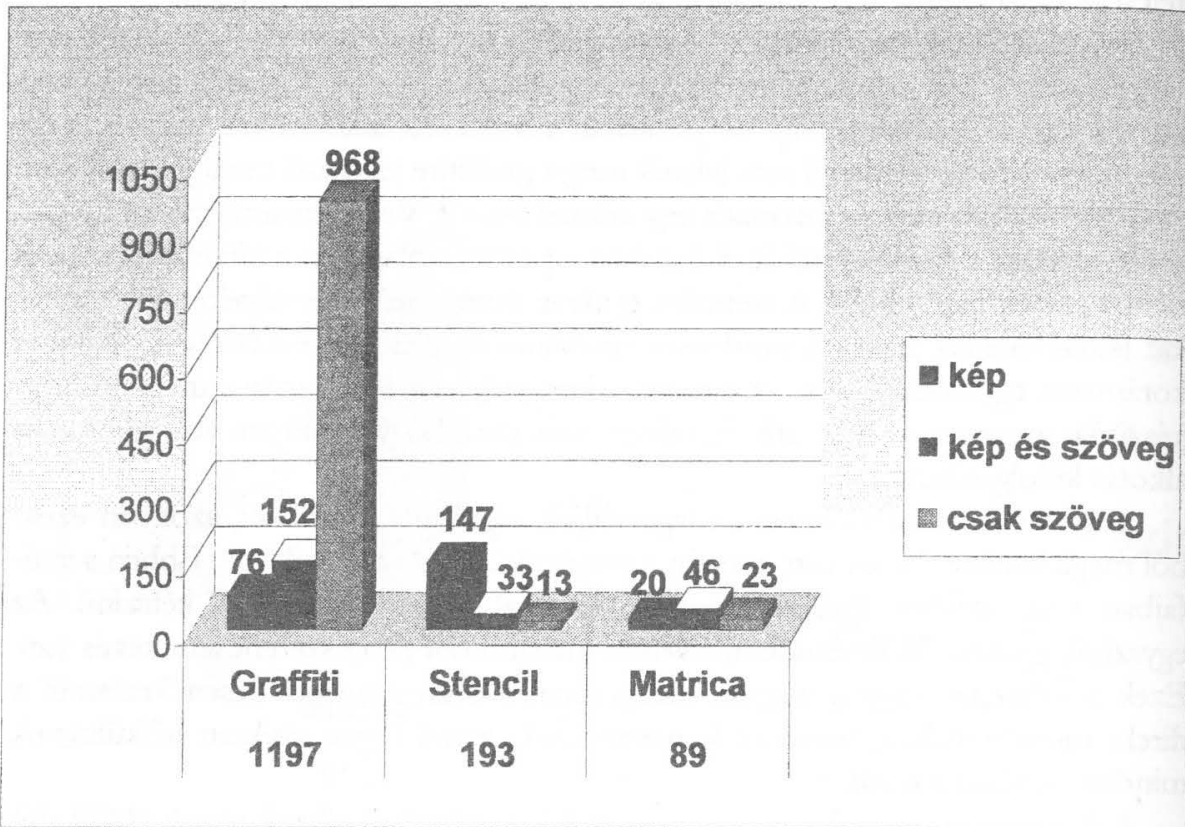

A vizsgálatban nagy szerepet kapott az, hogy megkülönböztessük egymástól az alkotásokat úgy, hogy mit és miként ábrázolnak. Itt megkülönböztettünk hátom kategóriát: képi ábrázolás, kép és a szöveg együtt és szöveg önállóan.

A szöveges ábrázolásmód a graffitiben jelent meg leginkább, ez mind a szubkultúra sajátosságaiból fakad, hiszen a graffitisek elsôsorban saját, illetve bandájuk nevét vagy annak röviditett változatát írják fel. Egyszerủ filccel felírt szignók, absztrakt vagy kövér betük kontúrral vagy anélkül. A figurális, vagyis karakterisztikus ábrázolásmód is megjelenik a graffitiben, de az elôzőhez képest ez igen csekély arányban. A firkálók képein néha megjelenik saját maguk vagy egy olyan karakter, amivel azonosítiák magukat, nem ritkán képregényszerủ ábrázolási módban. A karakternek a tehetség megmérettetésében lehet nagy szerepe, sok festéket és idôt igényel, ezért általában csak legál falakon találkoztunk velük. Ezeket a karaktereket általában valamiféle szöveg vagy tag kísérti, többnyire az alkotó neve jelenik meg. Mindez azt mutatja, hogy a tageket el lehet (és voltaképpen kell is) választani a graffiti nemesebb válfajától, de teljes mértékben mégsem lehet, mett a müfaj okán összetartoznak. A két színből álló graffitik soha nem egyszerũ tagek, ha alapvetố céliuk a szignó megielenítése, még akkor sem. A kutatás során éppen a szín válik választóvonallá a graffiti és az egyszerũ tag között.
A stencilek esetében már teljesen más a helyzet. Látható a diagrammból, hogy 2 stencilek esetében a képi ábrázolás a leggyakoribb, mindez ismét bizonyítja, hogy a vizuális képi ábrázolás elsősorban a stencilekben jelenik meg. A stencilezők szándékai közé tartozik a hirdetésekkel, reklámokkal való szembeszállás. Úgy akamak valamit kifejezni, mondani - csak olvasni kell belölük -, hogy a nézỏ közben használja a fantáziáját és a képzelỏerejét. Olykor polgárpukkasztó módon, olykor pedig világosan és egyértelmủen mutatnak valamit, vagy egyszerüen csak müvészien és gondosan , dekorálnak".

A matricáknál az összetett ábrázolás a jelentősebb. Egy ábra vagy karakter megjelenik a képeken, amit szöveggel is kibôvítenek. A matricán a szöveg hordozza leginkább a jelentést, és nem a kép, a kép csak a kiegészítõ elem. Nem úgy, mint a stencilnél, ahol ennek pont az ellenkezője történik. A matrica elsôsorban direkt üzeneteket hordoz, azt a kép csak ámyalja. A stencilnél a képi megjelenítésen van a hangsúly, annak kell erôsnek lennie, a szöveg csak kíséret.

Nagyon fontos tehát levonnunk azt a következtetést, hogy az esetek döntő többségében, mind a három utcamưvészet esetében eltérốek az ábrázolásmódok. Persze mindenhol akadnak átfedések, de az ábrázolásmód különbségei az egyes mưvészeti fotmák sajátosságaira mutatnak.

Az alkotásoke általános állapota

\section{5. ábra: Az alkotásoke általános állapota (db)}

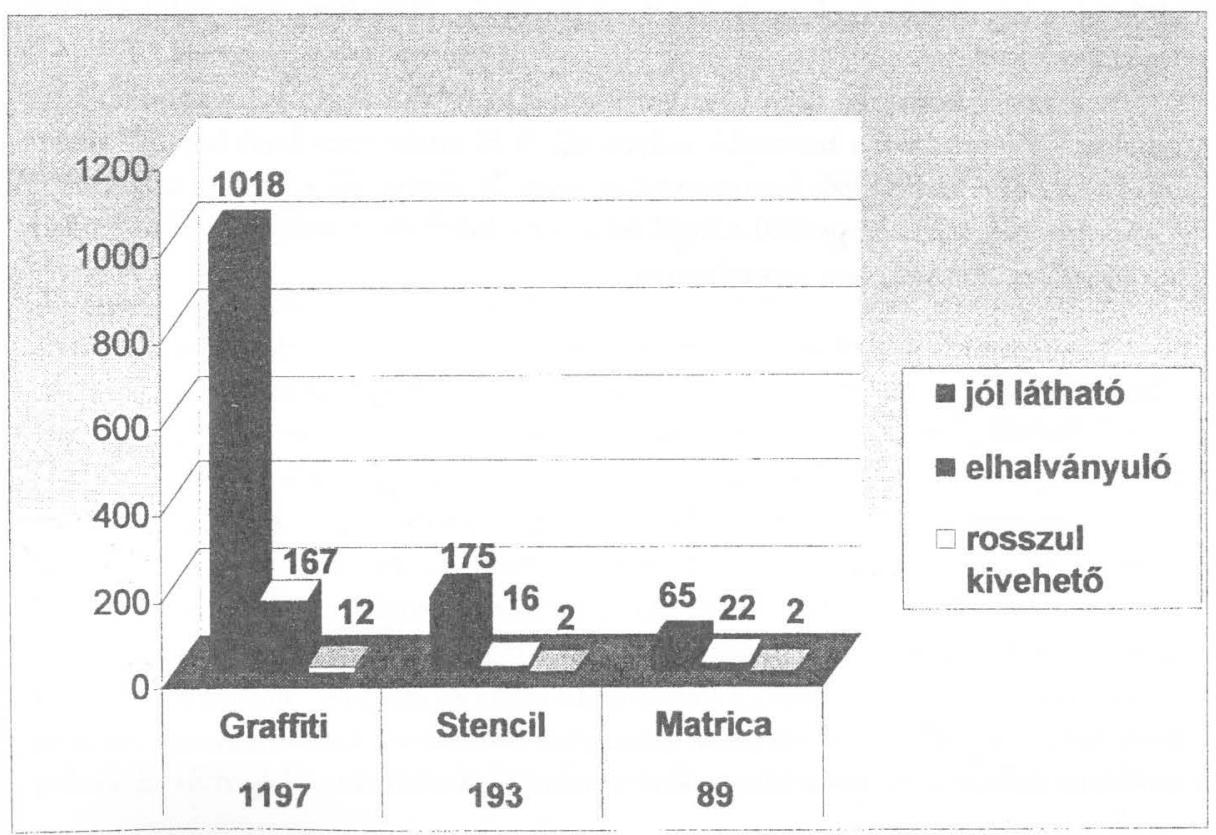


A mintánkat alkotó mứvek aktuális állapotát három kategória szerint különítettünk el: jól látható, elhalványuló, rosszul kivehetô. Elmondható, hogy a legtöbbje jó állapotban van, ami bizonyára sokakat elkeserít, szem elốtt tartva azt a tényt hogy ezek a mû̉vészeti formák sokszor rombolólag hathatnak. Föként akkor, ha csupán egyszerủen felvitt tagként vagy akár egy szétfolyt rossz minôségủ stencilként jelennek meg a vátos épületein.

A Pécsett fellehetô dekoratív, gondosan kidolgozott graffitik többsége a perifetikus területeken lévô legál falakon vagy elhanyagolt területeken található. Ezzel szemben a várost inkább romboló, az esztétikai élményt alig nyújtó firkák inkább lakott, belvárosi övezetben találhatóak. Ennek az az oka, hogy a graffitisek nevüket területmegjelölő céllal festik fel, minél forgalmasabb, látogatottabb helyen teszik ezt, annál jobban növelik saját presztizsüket a csoportban.

\section{Terïleti eloszlás}

A street artos jelek eloszlása a városban nem egyenletes. Az ábrán jól látható, hogy a belvátos a leginkább preferált hely, ahogy ez várható volt. A történelmi belvátosban viszonylag kevés a graffiti színes, nagyméretủ változata, mert nincs elég szabad és nagy falfelület, annál több viszont az elmenöben felfirkált egyszerú tag. A tágabb belváros (az ábra 3. kiugró oszlopa) az állomás kömyéke, ahol nemcsak az állomás keritései, de a felüljáró nagy betonoszlopai is kínálják a nagy felületet a színes graffitik számára. A régen diszkóként használt, kiégett Boccaccio falait legál falként használták a graffitisek. Az épületet azóta lebontották, a falakkal együtt eltüntek a képek és rajzok is. A street art mulandó, csak digitalizált fotókon élnek tovább a képek.

Az állomás környéke után Uránvárosban a legtöbb a street artos munka, a történelmi belváros csak a harmadik helyen áll. A Kertvárosban lakó fiatalok alapvetỏen graffitivel dekorálják környezetüket, stencilt elenyészỏ számban találtunk. A Gyárvárosban talált 86 graffiti a legál falon és a környékén van, közötttïk értelemszerúen sem matrica, sem stencil nincs.
6. ábra: Az alkotások területi eloszlása (db)

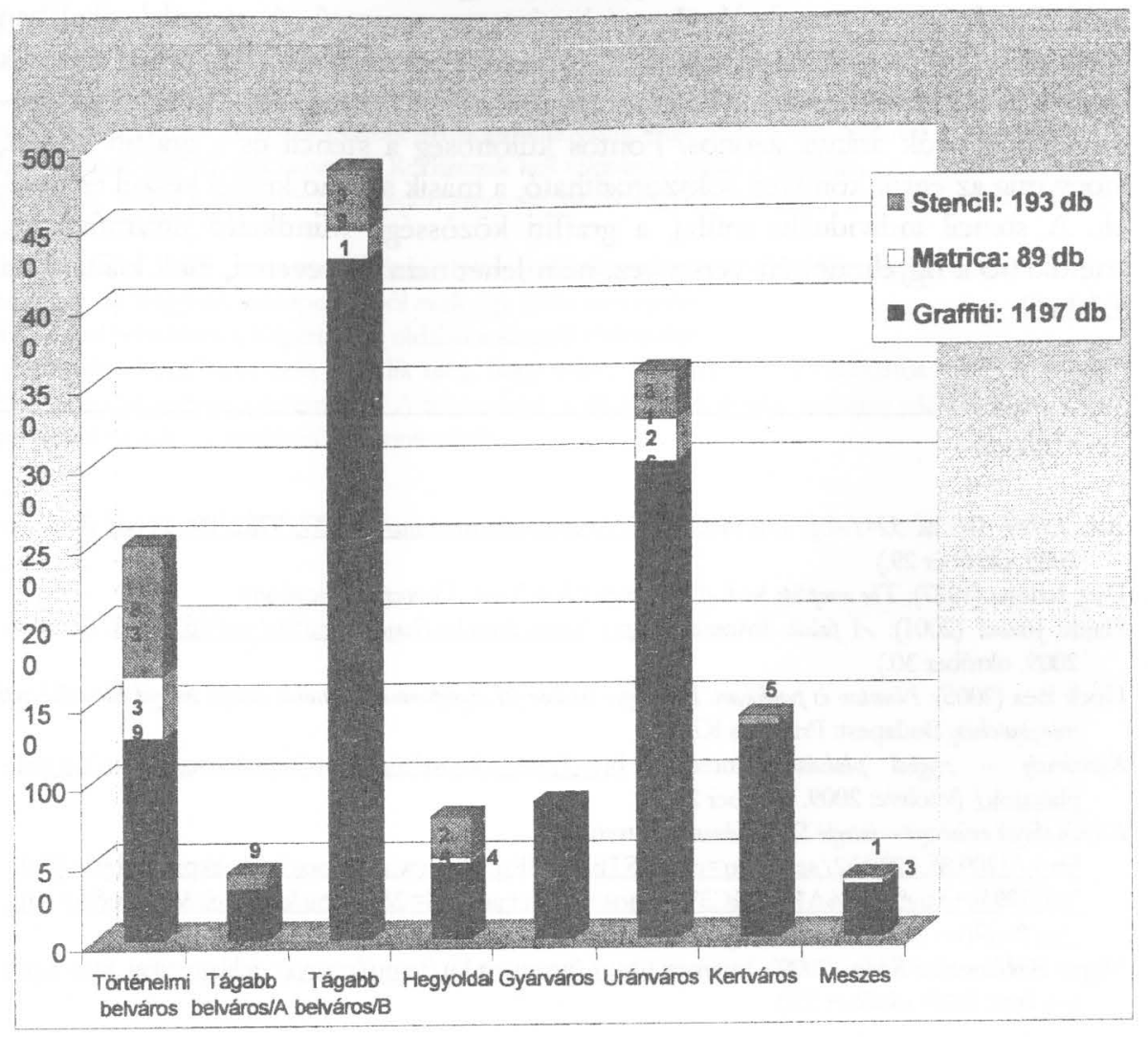

Összegzés helyett

A street art három mủfaját vizsgálva az adatok elemzése után nyilvánvaló, hogy a stencil és a matrica összetartozó mủfajok, nemcsak a sokszorositás technikai lehetőségei miatt, hanem valószinuzleg a készítők személye miatt is. Elterjedtségük is általában a belvárosban és annak tágabb kömyezetében jellemzỏ, kivétel Uránváros, ahol viszont a kollégium és az egyetem közelsége közrejátszhat a gyakori elổfordulásukban. A graffiti szinte mindenütt jelen van valamilyen mértékben, de a belvárostól távolodva szaporodnak a színes karakterek. A graffitik többsége különbözổ mélységig kidolgozott, sajátos stillust célzó betưkbőol áll. A dokumentációs munka során felvett graffitik 41\%-a legalább három szint tartalmaz, ezek az igényesebb alkotások. Pécsett az adott időszzakban a graffitik $80 \%$-a betúszöveg volt, neveket, bandaneveket jelenítettek meg a rajzolók, melyek elsősorban saját létezésükről és téffoglaló szándékukról tudósították a többieket. A stencilek esetében a 
helyzet éppen fordított, 76\%-uk kép, ennek megfelelően ezek az egyszínủek, mivel többrétegũ színes stencilt létrehozni korántsem egyszerũ. A stencilek általában valamiféle többletjelentést hordoznak, amivel egy tágabb közönséghez akarnak szólni. A matricák fele képet és szöveget is tartalmaz, a csak képet vagy csak szöveget hordozók aránya azonos. Fontos különbség a stencil és a graffiti között hogy mig az egyik könnyen sokszorositható, a másik szabad kézzel készül és egyedi. A stencil individuális müfaj, a graffiti közösségi. Mindkettổ utcamûvészet, mindkettő a figyelmünkért versenyez, nem lehet nem észrevenni, ránk kiáltanak a falaktól.

\section{Irodalom}

Btk 1978/ IV.tv. 324/A.f. Internet http://www.parlamenthu/irom37/9782/09782.pdf (letöltve: 2009. október 29.)

Day, Joanna (1987): The complete book of stencilcraff. New York: Dover Publications

Hajdú József (2001): A falak. Intemet http://www.dura.hu/hajdu graffiti/graffiti2.html. (letöltve 2009. október 30.)

Hock Bea (2005): Nemtan és pablikant. Lebetséges értelmezési szempontok az utábbi márfel évtized két müvészet irányzatáboz: Budapest Praesens Kiadó

Képtelenség - szegedi plakátok. Intemet http://www.keptelenseg.hu/keptelenseg/olvas/szegediplakatok/ (letöltve: 2009. október 29.)

Kriminakizált minvészet - interjú Sugár Jánossal Internet:

http://209.85.129.132/search?q=cache:SThsiZd3RqMI:www.antropos.hu/cikkprint.php\%3Fid

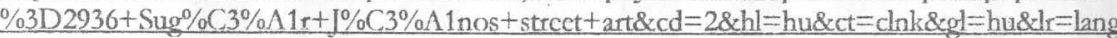
hu (letöltve: 2009. október 29.)

Magyar Reklametikai Kódex (2009). Intemet http://www.orthu/temp/magyar reklametikai kodex.pdf (letöltve: 2009. október 28.)

\section{Jegyzetek}

1 A Pécsi Tudományegyetem Bölcsészettudományi Kar Szociológia Tanszékénck infrastruktúräja biztosította a hátteret Gáspár Gabriella egyetemi docens vezette kutatáshoz, amely a Vizuális Mühely keretében, a tanszék hallgatóinak közremúködésévcl zajlott. A kutatás 2005 végén indult, de a jelen cikk arról a dokumentációs munkáról szól, amit 2007. március 15. és május 15. között végeztünk el, ekkor történt meg az adatok felvétele és a fényképen történô dokumentálás. A digitális fényképek rendezése, szerkesztése Schwiegelhoffer Bence érdeme.

${ }^{2}$ (2) ,A büntetés vétség miatt két évig terjedỏ szabadságvesztés, közćrdekũ munka vagy pénzbünte tés, ha a) a grafitizés kisebb kárt okoz, b) a szabálysértési értékhatárt meg nem haladó kárt okozó grafitizćst csoportosan követik el, vagy c) a szabálysértési értékhatárt meg nem haladó kárt okozó grafitizćst kulturális javak körébe tartozó tárgyon, régészeti lelőhelyen, mũemléken, vallási tisztelet tárgyán, vallási szertartás végzésére szolgáló épületen vagy tárgyon, temetési helyen, temetkezési emlékhelyen, temetöben, temetkezési emlékhelyen a halott emlékére rendelt tárgyon, középületen vagy tömegközlekedési jámművön követik el. 3) Büntett miatt egytỏl öt ćvig terjedố szabadságvesztéssel büntetendỏ az, aki a) nagyobb kárt okoz, vagy b) kisebb kárt okoz, és azt a (2) bckezdés b-c . pontjảban irtak szerint valósitja meg. (4) A büntetés kettōtöl nyolc ćvig terjedỏ szabadságvesztés, ha a grafitizés a) jelentổs vagy azt meghaladó kárt okoz, b) nagyobb kárt okoz, és az a (2) bekezdés b-c. pontjában irtak szerint valósul meg." (Btt. 2004. évi tönúnymódositása, 324/A.S)

3 „A reklám olyan gazdasági tájékoztatás (hirdetés), amely a fogyasztót áruk, szolgáltatások igénybevételére hivja fel, illetve ôt ebbõl a célból befolyásolni kívánja, vagy pedig a fogyasztóval az áru tulajdonságát és használati módját ismerteti. Reklámnak kell tekinteni azokat a hirdetéseket (fizetett közleményeket) is, amelyek valamely gazdálkodó szervezet nevét vagy tevékenységét népszerúsitik." (Magyar Reklámetikai Kódex 2009)

${ }^{4}$ Hajdú József (2001) irása megkülönbözteti a graffitiket a leggyakoribb elôfordulási helyük szerint is, de tárgyunk szempontjából ezek egy része irreleváns.

${ }^{5}$ Erről lásd bôvebben a Képtelenség oldalán a szegedi plakátokat.

${ }^{6}$ A folyóirat lehetőségei nem engedik meg, hogy szines képeket vagy a streetartos múfajok színes térképes megjelenitését prezentäljuk. A fekete-fehér térkép fehér, szürke és fekete jelekkel nem bizonyult attraktívnak, így közlésétôl eltekintettünk. 